\title{
СИСТЕМНОЕ ИССЛЕДОВАНИЕ ПРОИЗВОДСТВА ЭНТОМОФАГОВ
}

\author{
Чернова И.С. \\ Инженерно-технологический институт «Биотехника» Наџиональной академии \\ аграрных наук Украинь, Одесская область, Украина \\ E-mail: bioischernova@ukr.net
}

\begin{abstract}
The work is devoted to a systems research of the production of entomophages, in particular, the issue of quality control of entomological products was considered, quality control criteria, influencing factors are highlighted. The object of research was the production processes of the entomophage Habrobracon hebetor and its host insect Ephestia kuehniella. A structural-parametric complex for assessing the quality of an entomophage has been developed Habrobracon hebetor and its host insect Ephestia kuehniella, technological complex for quality control of entomological products, as well as a product quality management algorithm.
\end{abstract}

Keywords: quality, entomological products, control, parameters, production, complex, process

\section{Введение}

В настоящее время получение энтомологической продукции гарантированного качества является актуальным вопросом промышленной энтомологии как одной из составляющих биологизации земледелия в Украине. При этом современное производство энтомофагов представляет собой динамическую систему с управлением и содержит сложную структуру технологических потоков (основных, дополнительных, 
обслуживающих), что требует использования новых подходов, в частности. информационных технологий. Основная цель информационной технологии получение необходимой для пользователя информации в результате целенаправленных действий по переработке первичной информации [1].

Внедрение информационных технологий в производство биологических средств защиты растений связано с необходимостью обработки значительного массива данных, касающихся зависимости качества продукции от параметров процессов производства. Известно использование информационных облачных технологий, которое позволяет контролировать критически важные этапы технологического процесса массового разведения энтомофагов [2].

Контроль качества энтомологической продукции является важным условием эффективности производства. В настоящее время критерии контроля качества насекомых разделяют на общие и целевые; общие оценивают степень приспосабливаемости культуры к искусственным условиям разведения (техноценозу) и возможность ее воспроизводства, целевые - степень эффективности культуры при ее применении [3].

Качество энтомологической продукции определяется совокупностью полезных свойств (функциональных, экономических, органолептических), которые характеризуют ее товаропригодность. Качество энтомо- и акарифагов оценивается по количеству и массе яиц, проценту отрождения личинок, жизнеспособности, половому индексу и др. Первостепенное значение имеют процент заражения хозяев (для паразитов) или прожорливость (для хищников) [4]. Качество продукции непосредственно связано с технологией производства. Контроль абиотических параметров (температуры и относительной влажности воздуха бокса для развития энтомокультур, температуры питательной среды) уменьшает вероятность получения некондиционной продукции.

Качество энтомологической продукции в условиях техноценоза как замкнутой биотехнической экосистемы [5] зависит от многих факторов, среди которых необходимо отметить точность и стабильность поддержания температуры и относительной влажности воздуха бокса для развития энтомокультур в течение технологического цикла, вид питательной среды насекомого-хозяина [6], высоту ее слоя [7], чистоту маточной культуры, плотность содержания насекомых, надежность оборудования, уровень организации производства.

\section{Материалы и методы}

Объект исследований - процессы производства энтомофага бракон (Habrobracon hebetor) и его хозяина мельничной огневки (Ephestia kuehniella). На сегодняшний день известно, что бракон является эффективным энтомофагом в комплексной борьбе с вредителями чешуекрылыми (Lepidoptera) [8]. При разведении бракона в искусственных условиях использование в качестве насекомого-хозяина мельничной огневки является экономически целесообразным и дает возможность получать паразита с высокой поисковой способностью [7].

Методы исследований - системный подход, функциональное моделирование.

\section{Результаты и обсуждение}

Разработан структурно-параметрический комплекс оценки качества энтомофага бракон и его хозяина мельничной огневки (рисунок), который отображает сложные взаимосвязи между показателями качества насекомых и параметрами техноценоза. 


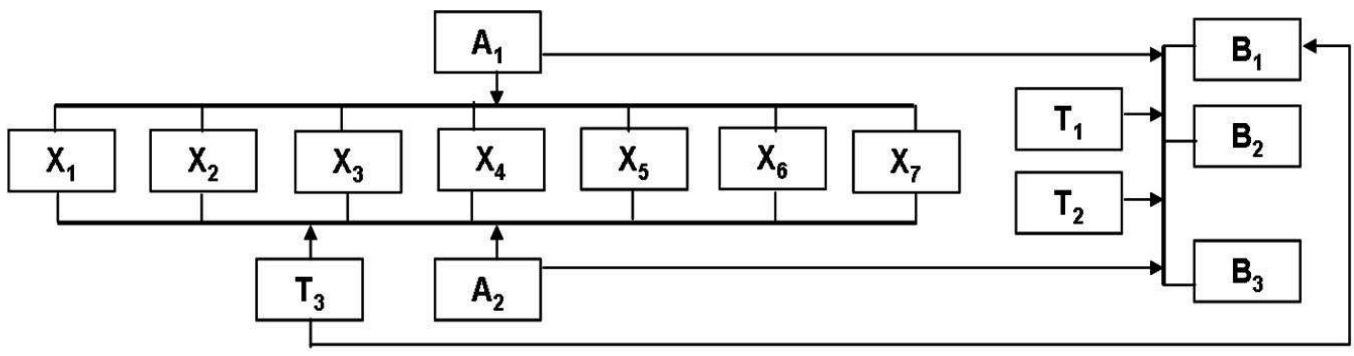

$\left(\mathbf{X}_{1}-\mathrm{X}_{7}\right)$ - показатели качества энтомофага бракон:

$\mathbf{X}_{1}-$ количество имаго с 1 самки, шт.

$\mathbf{X}_{2}-$ средняя выживаемость личинок, \%

$\mathbf{X}_{3}-$ количество самок имаго, $\%$

$\mathbf{X}_{4}$ - среднее количество имаго с 1 гусеницы, экз.

$\mathbf{X}_{\mathbf{5}}$ - среднее значение чистой репродукщи самок бракона, экз.

$\mathbf{X}_{6}-$ длительность развития, суток

$\mathbf{X}_{7}-$ количество зараженных браконом гусенищ мельничной огневки, \%

\footnotetext{
$A_{1}-A_{2}-$ абиотические параметры:

$\mathbf{A}_{1}$ - температура воздуха, ${ }^{\circ} \mathrm{C}$

$\mathbf{A}_{2}$ - относительная влажность воздуха, \%

$B_{1}-B_{3}$ - показатели качества мельничной огневки:

$\mathbf{B}_{1}$ - масса гусенищ старшего возраста, мг

$\mathbf{B}_{2}$ - масса гусени, мГ

$\mathbf{B}_{3}$ - колнчество гусенщ с 1 кт питательной среды, шт.

$\mathbf{T}_{1}-\mathbf{T}_{3}$ - технологические параметры:

$\mathbf{T}_{1}$ - количество янщ мельннчной огневки, внесенных в питательную среду, мг/кт

$\mathbf{T}_{2}$ - высота споя питательной среды, мм

$\mathbf{T}_{3}-$ вид питательной среды
}

Рисунок - Структурно-параметрический комплекс оценки качества энтомофага бракон и его хозяина мельничной огневки

Разработан технологический комплекс контроля качества энтомологической продукции, в основе которого лежит системный подход. Структура комплекса является иерархической и ориентированной на сбор и обработку информации об абиотических параметрах развития насекомых (температуре и относительной влажности воздуха бокса для развития энтомокультур, температуре питательной среды). Верхний уровень представляет собой автоматизированное рабочее место на базе персонального компьютера, адаптера интерфейса, программного обеспечения и выполняет такие функции, как отображение текущих значений приборов, ведение постоянного контроля работы приборов, расчет и оптимизация показателей качества. Нижний уровень содержит комплекс приборов для контролирования и регулирования абиотических параметров, а также оценки качества энтомологической продукции.

Оценивание процессов производства осуществляется с помощью мониторинга в режиме реального времени с помощью персонального компьютера, адаптера интерфейса USB/RS-485 AC-4 OBEH, SCADA программы OWEN PROCESS MANAGER (OPM) v.1.2; измерителя-регулятора ТPM 202 OBEH; измерительного модуля МВА8 ОВЕН; датчиков температуры и влажности [9].

Алгоритм управления качеством энтомологической продукции включает:

- контроль параметров процесса производства;

- контроль качества энтомокультур по определенным показателям;

- установление взаимосвязи между показателями качества и параметрами процессов;

- поиск оптимальных параметров производства.

\section{Выводы}

Предложенные подходы реализованы в процессе лабораторного производства энтомофага бракон и его хозяина мельничной огневки и могут быть полезными при 
создании технических систем управления производством энтомофагов с целью повышения его эффективности.

\section{Библиография}

1 Грицунов О. В. Інформаційні системи та технології: навч. посіб. Харк. нац. акад. міськ. госп-ва. Х.: ХНАМГ, 2010. 222 с.

2 Богатырев О. Д. Интеграция информационных технологий в технологии массового разведения агентов биологического контроля вредителей сельхозкультур. Матер. Междунар. науч.-практ. конф. «Биологическая защита растений - основа стабилизации агроэкосистем» с молодежной стратегической сессией «Кадры, ресурсы, возможности, инновации». Краснодар. 20-22 сентября 2016 г. С. 212-215.

3 Маркина Т. Ю. Новые подходы к контролю качества культур насекомых при разведении. Вісник Дніпропетровського університету. Біологія, екологія. 2016. № 24 (1). С. 164-172.

4 Шпатова Т. В., Штерншис М. В. Технологии производства биопрепаратов, энтомофагов и биологически активных веществ. Новосибирск, Новосиб. гос. аграр. унT, 2012. $42 \mathrm{c}$.

5 Злотин А. 3. Техническая энтомология. Справ. пособ. К.: Наукова думка. 1989. 183 c.

6 Молчанова Е. Д., Лешишак А. В., Шейкина Е. Б. Влияние кормового субстрата для выкармливания гусениц мельничной огневки на биологические показатели бракона. Матер. VI Междунар. науч. конф. «Чтения памяти проф. И.И. Барабаш-Никифорова». Воронеж. 25 марта 2014 г. Изд. дом ВГУ. Воронеж. 2014. С. 105-108.

7 Молчанова О. Д., Копко I. А. Розведення млинової вогнівки для вирощування ектопаразиту бракон (Habrobracon hebetor Say.). Аграрний вісник Півдня. 2014. № 1. C. 131-134.

8 Borzoui E., Naseri B., Mohammadzadeh-Bidarani M. Adaptation of Habrobracon hebetor (Hymenoptera: Braconidae) to Rearing on Ephestia kuehniella (Lepidoptera:Pyralidae) and Helicoverpa armigera (Lepidoptera:Noctuidae). Journal of Insect Science, 2016. V. 16. Iss. 1. P. 1 - 7.

9 Пат. на корисну модель № 106355 UA, МПК51 А01K 67/00, G07C 3/14. Спосіб керування якістю ентомологічної продукції / В. М. Бельченко, І. С. Чернова; заявник та патентовласник ITI «Біотехніка». - № u 201509944; заявл. 12.10.2015; опубл. 25.04.2016, Бюл. № 8. 